\title{
Det problematiske mangfold
}

GørILL NILSEN*

Title: The problematic plurality.

Abstract: Recent years have brought a greater focus on the need for museums to reflect the multi-cultural society of which they are a part. In Sweden, Norway and the $E U$, this has resulted in the designation of special years to land the idea of cultural diversity.

This article describes how the Nord-Troms Museum in Norway has worked to present the cultural history of Norwegians, Kvens and the Sami people. The museum has focused its presentation work on buildings and artefacts that represent particular features of ethnicity. At the same time, the museum is attempting to challenge the usual perceptions and stereotypical thinking associated with what is considered characteristic or typical for such features.

However, there are political and organisational implications associated with working within a cultural history context in which a majority population (the Norwegians), an indigenous people (the Sami) and a national minority (the Kvens) all have their place. The background for the Norwegian state's understanding of what constitutes cultural diversity in practice does not necessarily coincide with the views held by the Sami Parliament of Norway, or the organisations representing the Kvens. These implications make museum work that focuses on such issues into quite a challenge.

Key words: Museum, cultural diversity, ethnic minorities, indigenous peoples, rights, institutional structure.

\section{FOKUS PÅ KULTURELT MANGFOLD}

Diskusjoner omkring og analyser av kulturelt mangfold $\mathrm{i}$ museer har de senere år blitt et sentralt tema innenfor museologisk forskning, både i Norge og andre land. I Norge ble dette diskutert på Norsk ICOM-møte allerede i 1993 (se Øye et al. 1994). I NOU 1996: 7 (s. 66-67, 215) Museum. Mangfald, minne, møtestad ble det påpekt at museene skulle satse på formidling knyttet til den flerkulturelle samtidsvirkeligheten. Temaet ble så tatt opp i prosjektet Norsk museumformidling og den flerkulturelle utfordringen (Rekdal 1999) i regi av Norsk museumsutvikling. ${ }^{1}$ Her ble imidlertid temaet urfolk og nasjonale minoriteter holdt utenfor debatten.

Internasjonalt har det blitt publisert en rekke undersøkelser som har vist at utstillinger som berører kulturelt mangfold kan fremme positive relasjoner mellom etniske grupper. Gjennom utstillinger kan informasjon om 
140 grupper nå et større publikum, for på denne måte å øke bevisstheten om gruppen i et storsamfunn. Det etableres også en møteplass hvor ulike fordommer kan konfronteres. (se for eksempel Hooper-Greenhill 1996, Karp \& Lavine 1991, Karp, Kreamer \& Lavine 1992, Sandell 2002, 2003).

Denne debatten, som altså lenge har vært viktig innenfor museologien, har nå også nådd nivået hvor politiske slutninger tas. Sentrale myndigheter og minoritetsgrupper legger føringer på hvordan kulturelt mangfold skal forstås og presenteres i museer. Minoriteter er med andre ord ikke bare et objekt for utstillinger, men skal være aktivt deltakende i prosesser der egen historie og kultur presenteres.

I denne artikkelen vil jeg se nærmere på noen av disse føringene, og hvordan de helt konkret virker inn på hverdagen $\mathrm{i}$ et museum $\mathrm{i}$ en fleretnisk region i Norge.

\section{KULTURELT MANGFOLDSÅR}

Gjennom sentralpolitiske føringer har mangfold blitt et begrep som har fătt stor innvirkning på kultursektoren generelt, og museumsvesenet spesielt. Sveriges Mångkulturåret 2006 (SOU 2007:50 Mangfåld är framtiden) er sluttført, mens Norges Kulturelt mangfoldsår 2008 ${ }^{2}$ avvikles parallelt med EUs European Year of Intercultural Dialogue. ${ }^{3}$

Markeringsårenes ideologiske grunnlag bygger i stor utstrekning på FNs konvensjoner om ikke-diskriminering og likebehandling ${ }^{4}$ samt Unescos konvensjoner om kulturelt mangfold; henholdsvis Universal declaration on cultural diversity ${ }^{5}$ fra 2001, Convention for the Safeguarding of the Intangible Cultural heritage ${ }^{6}$ fra 2003 og Convention on the protection and promotion of the diversity of cultural expressions $^{7}$ fra 2005.
De siste årene har det vært et økende fokus på nettopp urfolks og nasjonale minoriteters historie og kultur i museer. Dette har blant annet kommet til uttrykk i Stortingsmelding nr. 15 (2000-2001) Nasjonale minoriteter i Noreg og videre blitt fulgt opp av ABM-utvikling ${ }^{8}$ gjennom Arkivene, bibliotekene, museene og De nasjonale minoritetene (Holmesland 2006). Sametinget har også viet særlig interesse for etablering og konsolidering av samiske museer gjennom Sametingrådets melding om samiske museer $2004 .^{9}$

Hensikten med markeringsåret kan på mange måter oppfattes som en synliggjøring og en oppfølging $i$ praksis av konvensjonenes målsettinger i en nasjonal kontekst. Norge er et land med etnisk, kulturelt og religiøst mangfold, og dette skal fra 2008 gjenspeiles i kulturlivet. Målene for markeringsåret viser seg ambisiøse, men ser samtidig ut til å være svært generelle. Selv om markeringsåret har alle som bor i Norge som målgruppe, både aktører og publikum, skal et særlig fokus rettes mot urbefolkningen, nasjonale minoriteter og minoriteter som er kommet til Norge som følge av nyere migrasjon. Kulturaktører skal synliggjøre og styrke det mangfoldet som allerede finnes, det skal skapes samhandlingsarenaer mellom majoritets- og minoritetskulturer på samme tid som minoritetene skal utøve og videreutvikle egne kulturaktiviteter. På denne måten skal både offentlig finansierte kulturaktører og publikum gjenspeile, respektere og øke kunnskapen om det kulturelle mangfoldet. Disse målsettingene blir betraktet som langsiktige strategier, og er ikke ment som områder som kun skal vies en særlig oppmerksomhet inneværende år. ${ }^{10}$

De fleste vil utvilsomt synes intensjonene som ligger til grunn for markering av en flerkulturell virkelighet er gode. Skal et museum 
bli fullt ut flerkulturelt, vil en imidlertid kunne støte på hindringer, blant annet av politisk eller organisatorisk karakter. Dette er i alle fall de erfaringene som jeg har gjort etter å ha vært ansatt ved Nord-Troms Museum i fire år, hvorav tre som førstekonservator og ett år som bestyrer.

\section{NoRd-Troms Museum - ETt Museum og EN REGION}

Nord-Troms Museum er lokalisert i de seks kommunene Lyngen, Storfjord, Kåfjord, Nordreisa, Skjervøy og Kvænangen. Området har vært, og er, preget av tilstedeværelsen av flere etniske grupper. Arkeologiske funn viser at regionen har vært bebodd siden eldre steinalder. Strukturer og løsfunn fremviser stor variasjon og dokumenterer tilstedeværelsen av en overveiende samisk befolkning frem til og med 1700-tallet. Fra 1700-tallet av viser både kulturminner og historiske kilder et større innslag av kvener og nordmenn, selv om disse gruppene også tidligere har vært bosatt i området.

Nord-Troms fremstår i dag, i alle fall ved første øyekast, som et svært enhetlig område hva materiell kultur vedrører. Det er først og fremst to årsaker til dette. For det første var statens fornorskningspolitikk sterk, særlig fra midten av 1800-tallet av. Offentlig virksomhet, som skole og kirke, fremmet norsk språk og kultur. Selv om årsakene til fornorskningspolitikken er komplekse, må den først og fremst sees på bakgrunn av at nasjonen på denne tiden bygde opp en nasjonal identitet frem mot løsrivelsen fra Sverige i 1905. Norge skulle bli ett rike bestående av ett folk. Resultatet ble at både samisk og kvensk kultur kom under press, og norsk språk og kultur ble dominerende.

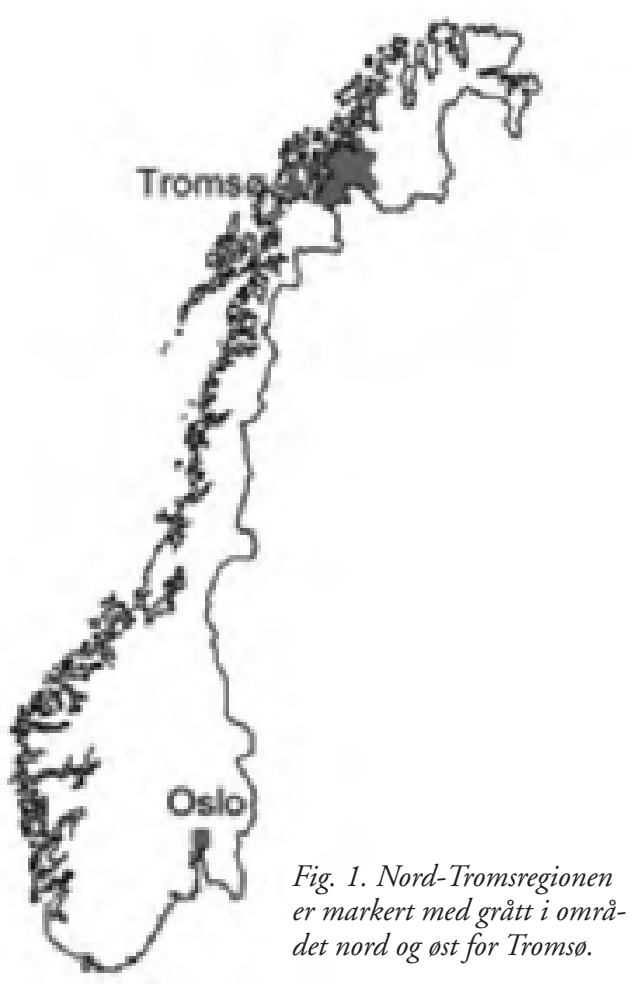

For det andre ble regionen hardt rammet av tyskernes brente jords taktikk i forbindelse med deres tilbaketrekking under andre verdenskrig. I store deler av området er det derfor svært få hus som er eldre enn krigen, og bygningene som ble satt opp under gjenreisningen ble svært ensartet. Samisk og kvensk kultur ble imidlertid aldri fullstendig utradert, og en sterk vitaliseringsbølge de siste tiårene, blant annet representert gjennom urfolksfestivalen Riddu Riddu ${ }^{11}$ i Kåfjord og kvenfestivalen Baaski ${ }^{12}$ i Nordreisa, har igjen ført til en større synliggjøring av Nord-Troms som en fleretnisk region.

Nord-Troms Museum er også en aktør som har arbeidet for synliggjøring av det etniske mangfoldet. Museet ble etablert i 1979. Bak- 


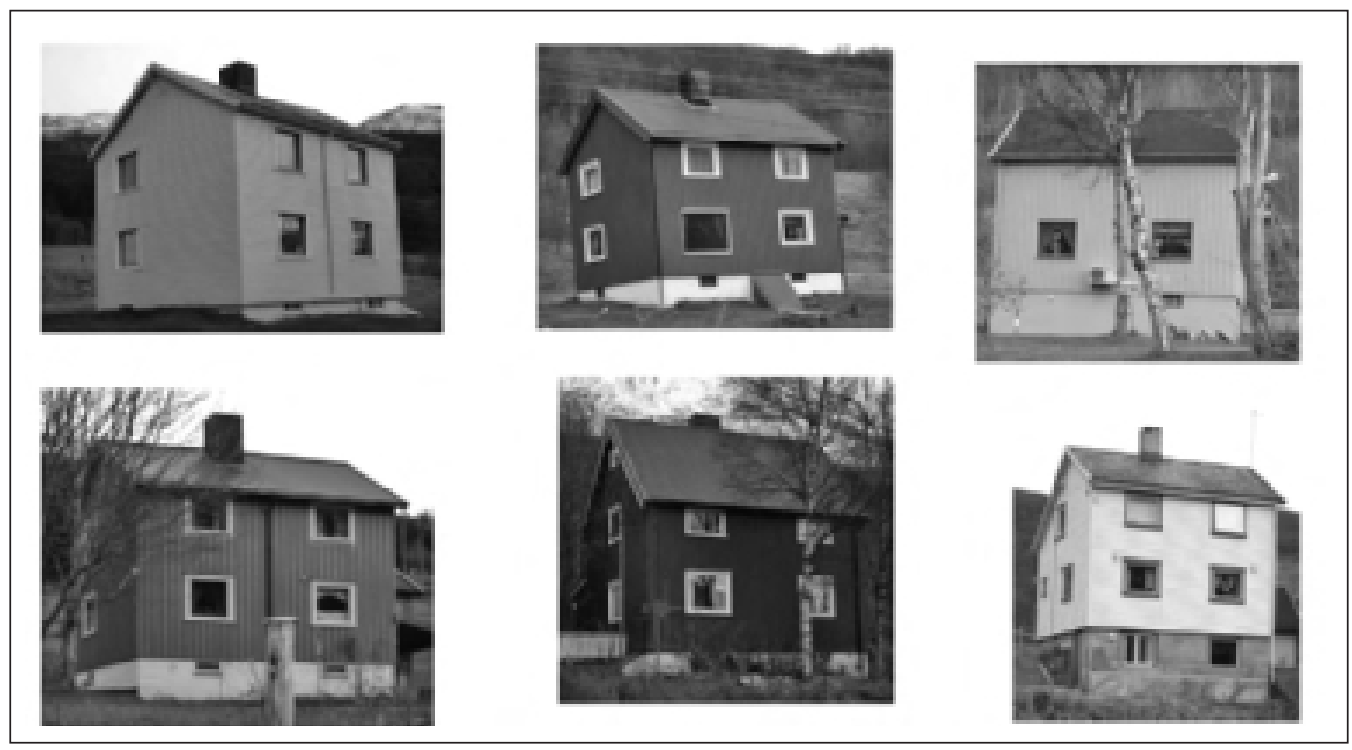

Fig. 2. Eksempler på gjenreisningsarkitektur. Foto: NTRM.

grunnen for grunnleggingen må sees i relasjon til den økte bevisstheten om Nord-Norges egenart og en radikalisering av det politiske klima. Denne prosessen ga mange utslag i løpet av 1970-tallet, fra etablering av nye museer og lokalhistorielag, den nordnorske visebølgen, danningen av Nordnorsk Forfatterlag og Hålogaland Teater til demonstrasjonene knyttet til utbyggingen av Alta-Kautokeinovassdraget (Nilsen 2004a).

På bakgrunn av denne konteksten valgte Nord-Troms Museum å bygge opp sin virksomhet tuftet på økomuseumsfilosofi. Museet består derfor i dag av 79 bygninger og 24 båter som er lokalisert i sin opprinnelige brukskontekst rundt om i en vidstrakt region. I hver av de seks kommunene konsentrerer museet formidlingen rundt ett hovedanlegg. Til sammen skal disse anleggene gi et tverrsnitt av områdets mangfoldige kulturhistorie og har som siktemål å formidle samisk, norsk og kvensk kulturhistorie på en likeverdig måte.

\section{DET TYPISKE}

Som nevnt har flere prosesser ført til at egenartet etnisk materiell kultur i stor utstrekning har blitt utradert i Nord-Troms. Samtidig har arkitektoniske uttrykk også til dels vært felles for alle gruppene som resultat av tett samkvem gjennom århundrer (se for eksempel Hage 2008). Likevel er det visse trekk som en først og fremst forbinder med én av de tre gruppene. Disse typiske, eller særetniske trekkene, har museet valgt å synliggjøre på Tørfoss kvengård og Holmenes sjøsamiske gård.

Samene anerkjennes som et urfolk da de som folk har bevart, helt eller delvis sin materielle kultur, verdier eller institusjoner samt at de levde i et visst landområde før storsamfun- 
net tok det over eller staten ble etablert jamfør ILO-konvensjon nr. 169. Etter isens tilbaketrekking ble landområdene i nord bosatt av folk som trolig var preget av lokal interaksjon mellom nokså likense samfunn. Den primære kollektive identitet var dermed knyttet til lokalsamfunnet i form av bands eller territorielle grupper, eller til slektsgrupper. Som følge av kontakt mellom de nordlige fangstsamfunnene og østlige metallproduserende bondesamfunn, utvikler den samiske etnisiteten seg i tidlige metalltid, 1800-0 f. Kr, og spesielt i det siste årtusen før Kristi fødsel (Hansen \& Olsen 2004:38).

I dag finner man flere distinkte språk og tilpasningsformer innenfor samisk etnisitet. I Nord-Troms eksisterer den reindriftsbaserte tilpasningen side om side med den sjøsamiske. Et av anleggene til Nord-Troms Museum formidler den sjøsamiske tilpasningen gjennom en gård som gjennom restaurering og rekonstruksjoner fremstår slik den gjorde på 1930tallet. Her finner en særdrag som en sjeldent finner i norske eller kvenske områder. På tunet ligger flere spesialfunksjonsbuer av oldertre. Husdyrene ble plassert i en fjøsgamme. I utmarka hadde gårdens folk skogslåtter, og her ble høyløe og sommerfjøs plassert. Nede ved fjorden var det ingen naust knyttet til gården, slik som var vanlig i norske områder, men ei fjærbu. I denne var det plass til fiskebruk, men ikke selve båten, og bua fungerte også som lagringsplass for varer som ble fraktet mellom havet og gården (Hage 1994, Nilsen 2004a).

På Tørfoss gård er det på tilsvarende måte den kvenske tilpasningen som står i fokus. Kvenene er ei folkegruppe som opprinnelig kom fra det nordlige Sverige og Finland, særlig fra Tornedalen, og slo seg ned i NordTroms og Finnmark. Fast kvensk bosetting er kjent fra 1500-tallet av, men økte i omfang på

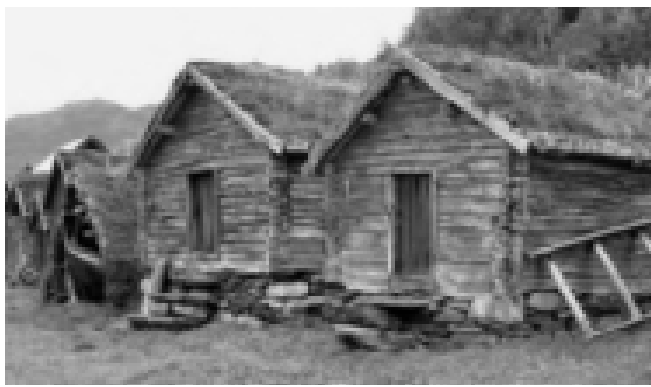

Fig. 3. Fjerbuer og naustgamme i Kåfjorden. Foto: NTRM.

1700- og 1800-tallet (Hage 1995, 2008). Kvenene er derfor en nasjonal minoritet da de har langvarig tilknytning til det landet de bor i samt at de i vesentlig grad skiller seg fra den øvrige befolkningen i den aktuelle stat med hensyn til etniske, språklige, kulturelle og/eller religiøse særtrekk.

På Tørfoss gård vektlegges formidling av materielle uttrykk som i særlig grad blir knyttet til kvenene: Eksempelvis er røykbadstua på gården bygd etter finske tradisjon. I kvensk mattradisjon sto bruken av rugmel sentralt, og i ovnen i bårdstua kunne opptil 20 brød steikes samtidig. Denne tradisjonen holdes ved like $\mathrm{i}$ formidlingsøyemed. På Tørfoss finner man også klare arkitektoniske særdrag som skiller denne kvenske gården fra norske. Alle innvendige vinduskarmer i våningshuset skråner for eksempel nedover mot en vannoppsamler plassert under karmen (Hage 1995, 2008).

Nord-Troms Museum har gjennom disse to gårdene bidratt til synliggjøring av det etniske mangfoldet i regionen. Det å skille ut og definere det typiske er imidlertid en strategi som er tveegget. Ved å fremheve Holmenes og Tørfoss som henholdsvis en sjøsamisk og en kvensk gård vil publikum få større innsikt i det særegne 


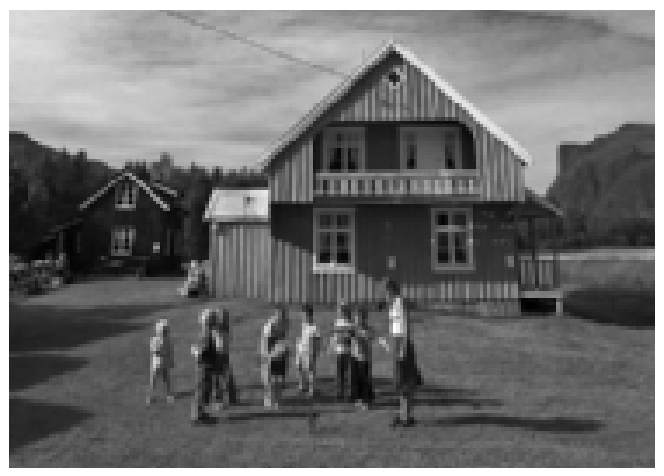

Fig. 4. Tørfoss i Reisadalen. Foto: NTRM.

eller det som er typisk for de ulike etniske gruppene. Dette er utvilsomt en viktig oppgave i en region som har gjennomgått en hard fornorskning og nedbrenning under krigen.

Samtidig er vektleggingen av det typiske med å tilsløre en kompleks virkelighet. Samisk, kvensk og norsk egenart blir utskilte og klart definerte, avgrensede størrelser. Virkeligheten i Nord-Troms er imidlertid også preget av hybridisering og kulturlån.

Denne hybridiseringen gir seg ikke bare utslag i den materielle kulturen. I Nord-Troms finnes folk, både i dag og i historisk tid, som definerer seg som enten norsk, kvensk eller samisk. Et særtrekk ved området er at det har vært utbredt med giftemål på tvers av de etniske gruppene. Resultatet er at mange har sin bakgrunn i både norsk, samisk og kvensk kultur (se tabell 1).

\section{A UTFORDRE FORESTILLINGENE OM DET TYPISKE}

Nord-Troms Museum er ikke nødvendigvis et mangfoldsmuseum når samisk, kvensk og norsk historie formidles hver for seg på "etnisk homogene" anlegg. Forestillinger om det ty- piske må og skal utfordres, om det komplekse mangfoldet også skal bli synlig. Et godt eksempel på hvordan dette har lyktes i praksis er måten Nord-Troms Museum har formidlet kunnskap om Nordlandsbåter på.

Nord-Troms Museum eier 24 båter, hvorav de fleste er Nordlandsbåter av ulik størrelse. Båtene har i formidlingssammenheng tidligere primært blitt satt i sammenheng med fiskerbondetilpasningen. Her har mennenes deltakelse i de store kommersielle vinterfiskeriene stått sentralt, mens kvinnenes rolle har vært knyttet til gårdsdrift på småbruk.

Fiskernes etnisitet har i liten grad vært problematisert. Resultatet har blitt at fiskerne $\mathrm{i}$ stor utstrekning har fremstått som norske menn. Dette har trolig flere årsaker. De kommersielle fiskeriene foregikk først og fremst på ytterkysten. Dette er områder hvor en tradisjonelt har hatt de største innslagene av norsk befolkning, og her har også fornorskningspolitikken hatt betydelig gjennomslagskraft. Når fisken var kommet opp fra havet, og skulle fraktes videre til Bergen for salg, var dette en handel som ble organisert av væreierne. Dette var en sosial klasse som i stor utstrekning hadde sine slektsbånd knyttet til områder lengre sør i Norge, sågar til andre land. Bildet av fiskeren som norsk mann har også blitt bygd opp gjennom skjønnlitteratur, slik som i Den siste viking av Johan Bojer (1921).

Det ble derfor sterke reaksjoner i lokalsamfunnet da både Nord-Troms Museum og en lokal $4 \mathrm{H}$ klubb ga sine nybygde Nordlandsbåter samiske navn og betonte at det dreide seg om samiske Nordlandsbåter.

\section{B/EIVVE-ALgGo}

Nord-Troms Museum fikk i 2008 ferdigstilt en ny Nordlandsbåt av åttrings størrelse. Bå- 
ten ble bygd etter tegninger av en større båt som var i bruk på 1850-tallet i Kvænangen samt foto av båter benyttet under en kirkehelg i Kvænangen, også disse fra rundt 1850. På denne tiden var fjorden overveiende et samisk område (Bjørklund 1985).

Fra Segelvik i Kvænangen kom Anders Larsen (1870-1949), som sammen med sine brødre hadde en båt som gikk under navnet $\mathrm{B} x$ ivve-Alggo. Nord-Troms Museum valgte å gi den nybygde åttringen samme navn. Baivve$A_{\operatorname{lggo}}{ }^{13}$ (1912) er imidlertid også navnet på den første samiskspråklige skjønnlitterære roman, skrevet av nettopp Anders Larsen. Boka handler om den uutdannede samegutten Ábos utvikling mot å bli en voksen mann med politiske ambisjoner. Samisk egenverd er sentral tematikk i boka, men samtidig får leseren en følelse av oppgitthet og det å være minoritet i et norsk storsamfunn.

Larsen var også aktiv samepolitisk og ga fra 1904 ut avisa Sagai Muittalægje hvor han agiterte for at Isak Saba fra Varanger skulle komme inn på Stortinget i 1906, noe som også lyktes. Det var for øvrig i denne avisa at Saba fikk Sámisoga lávlla ${ }^{14}$ på trykk for første gang. Avisa hadde sin siste utgivelse i 1911 (Antonsen 2004:167).

Bæivve-Alggo er med andre ord ikke et hvilket som helst samisk navn. Navnet gir konnotasjoner som handler om samisk selvbevissthet og kamp mot fornorskningen.

Nord-Troms Museums navnevalg på Nordlandsbåten gikk ikke upåaktet hen. Dåpen av Bæivve-Alggo falt sammen i tid med uttalelser i media fra fartøyvernkonsulent Sverre Nordmo ved Nordnorsk fartøyvernsenter. I en rekke aviser ble Nordmos uttalelser om at Nordlandsbåtens friske farger hadde klare paralleller i samenes kofter, og at samene derfor hadde vært båtbyggere, gjengitt. Leserinnleggsider i avisene Framtid $i$ nord og Nordlys ble raskt fylt opp av SMS-innlegg hvor det ble gitt klart uttrykk for at det var fullstendig utenkelig at samer kunne ha noe med båter å gjøre, med referanse både til Nordmo og Nord-Troms Museums båt.

$\AA$ være ansatte ved Nord-Troms Museum på denne tiden ble derfor en interessant opplevelse. Det ble mange telefoner fra publikum som stilte seg kritisk til museets kobling mellom Nordlandsbåt og samer som byggere og brukere av disse.

At samer også var båtbyggere og brukere, er imidlertid godt belagt, og ble også formidlet, blant annet gjennom kronikk i avisa Nordlys (Nilsen \& Mathisen 2006). Fra Balsfjorden, Malangen, Kvænangen og Lødingen kjenner en til navngitte samiske båtbyggere (Hauglid 1981, Bjørklund 1985, Sundt 1976, Mathisen 2003). Samisk bruk av Nordlandsbåt har blant annet blitt dokumentert av Henry Minde (2000:28, 74-78) og Trygve Solhaug (1976: 267-279). Den samiske deltakelsen i fiskeriene er ikke bare noe som har foregått i nyere tid, men som er dokumentert tilbake til middelalderen i kilden Passio Olavi (Dahl Bratrein 1998). Etter at dette ble klart formidlet, stilnet debatten av.

Å utfordre det typiske, handler om å stadig skrelle nye lag av gjengse oppfatninger. Havet var ikke bare en arena for menn. Også kvinner var fiskere, og i Nord-Troms var disse kvinnene ofte samer. Einar Richter-Hanssen (2004: 80-83) navngir 22 kvinnelige fiskere i NordTroms. Richter-Hanssen (2004:81) påpeker følgende: "Med unntak av Storfjord var kvinnelige fiskere representert $\mathrm{i}$ alle distrikter. Vi kan også slå fast det var flest samer som drev dette yrket.". De sterke reaksjonene som museet har møtt gjennom å formidle at fiskeren og båtbyggeren kunne være noe annet enn en 


\begin{tabular}{|l|c|c|c|c|}
\hline & Samer & Kvener & Nordmenn & Blandet etnisitet \\
\hline 1845 & 1944 & 454 & 650 & \\
\hline 1855 & 2100 & 742 & 862 & \\
\hline 1865 & 2055 & 794 & 937 & 456 \\
\hline 1875 & 1546 & 709 & 798 & 1608 \\
\hline 1900 & 1992 & 320 & 1386 & 2662 \\
\hline 1920 & 2044 & 337 & 1551 & 3300 \\
\hline 1930 & 1612 & 527 & 2446 & 3138 \\
\hline
\end{tabular}

Tabell 1: Samer, kvener, nordmenn og folk med blandet etnisitet 1845-1930 i folketellinger fra deler av Nord-Troms (Richter-Hanssen 2004:53).

norsk mann har vist at det er nødvendig å få frem både et etnisk og kjønnsmessig mangfold knyttet til maritime aktiviteter. Denne erkjennelsen dannet grunnlaget for prosjektet Havets helter hvor Nord-Troms Museum, Nordvestsamisk Museumssiida Porsanger, Vadsø Mu-

Fig. 5. Flerkultur i praksis: Baivve-Alggo døpes under Riddu-festivalen i 2005. Gudmor er den maoriske vokalisten Mina Ripia i gruppa Wai (Havets gudinne). Foto: NTRM.

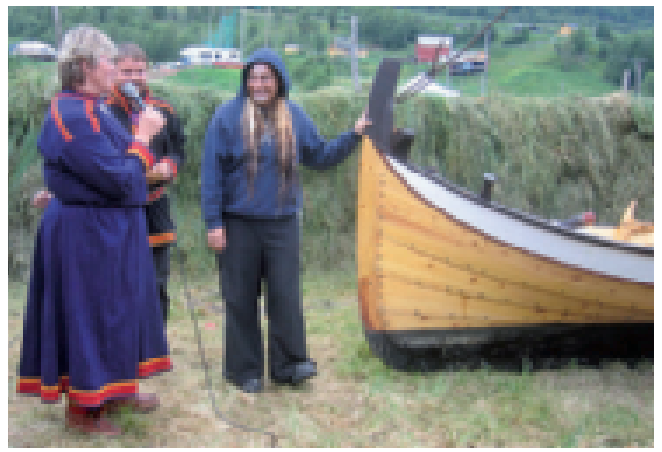

seum - Ruija kvenmuseum, Trondarnes Distrikstmuseum og Museum Nord avdeling Øksnes deltar under ledelse av Mariann Mathisen ved Nordnorsk fartøyvernsenter/Indre Sør-Troms Museum. Her er det nettopp synliggøøring av et historisk dokumentert mangfold knyttet til maritime aktiviteter som er det sentrale. Havet har nemlig vært en arena for både kvinner og menn, samer, kvener og nordmenn.

\section{StATENS SYN: SAMISKE MUSEER MED DELT FORVALTNINGSMESSIG TILKNYTNING}

Nord-Troms Museum er med andre ord et museum som formidler samisk, kvensk og norsk kulturhistorie. Denne historien formidles gjennom å fremheve hva som er typisk for de ulike gruppene, men også gjennom å utfordre de bildene som ofte skapes, og som også skapes av museet selv, av det typisk samiske, kvenske og norske. Samtidig har de som job- 
ber ved museet slektsrøtter i regionen - i både samisk, norsk og kvensk kultur. Betyr dette at Nord-Troms Museum er et fleretnisk museum? Eller mer presist; er museet tilstrekkelig samisk og kvensk til at det ikke bare er et norsk museum? Svaret vil avhenge av hvem som blir spurt.

I dag har Nord-Troms Museum sin forvaltningsmessige tilknytning til den norske stat ved Kultur- og Kirkedepartement (KKD). Retter man dette spørsmålet til staten, vil svaret bli at Nord-Troms Museum er et flerkulturelt museum. Av Stortingsmelding $\mathrm{nr} 15$. (2000-2001) Nasjonale minoritetar i Noreg Om statleg politikk overfor jødar, kvener, rom, romanifolket og skogfinnar kapittel 6.6.1 fremgår det at:

Det bør i framtida vere eit hovudprinsipp at kulturelt mangfald også skal vere synleg i arkiv-, bibliotek- og museumssamanheng. I visse høve kan det vere aktuelt med eigne institusjonar for ei folkegruppe. Samstundes er det viktig å setje i verk tiltak og finne løysningar som gir uttrykk for samkven, kulturmøte og samspel mellom ulike grupper. Det er ein kvalitet når arkiv, bibliotek og museum speglar slikt samkvem i regionar der dette er eit viktig kjennemerke. Det kan såleis ofte vere betre å knyte ansvar og tiltak til eksisterande institusjonar framfor å skipe nye. Med det er avgjerande at den aktuelle minoriteten er premissleverandør, og at tiltaket er ein del av gruppa sin innsats for å halde oppe og styrkje sin eigen kultur.

At institusjoner knyttet til KKD også burde kunne være samiske museer følger av dette. Et samisk museum ville en altså kunne tenke seg forvaltningsmessig tilknyttet både Sametinget og KKD. At en slik modell er akseptabel, har også blitt uttrykt fra ABM-utviklings ${ }^{15}$ side. I et brev fra ABM om Sør-Varanger Museums forvaltningsmessige tilknytning påpekes det at det er viktig at også staten tar ansvar for museer som arbeider med prioriterte felt som kulturmøter og kulturelt mangfold. ABM fremholdt videre at de ville anbefale for departementet å vurdere en løsning med delt statlig driftsstøtte mellom KKD og Sametinget. En slik delt forvaltning ble betraktet som noe som kunne virke positivt for samarbeid og samhandling (Brev fra ABM-utvikling ref. 05/148-4: Overføring av forvaltningsansvaret for Sør-Varanger Museum til Sametinget).

\section{SAMETINGETS SYN: SAMISKE MUSEER UNDER SAMETINGET}

Er Nord-Troms Museum et fleretnisk museum i følge Sametinget? Det kan det nok være, men Nord-Troms Museum er ikke å betrakte som et samisk museum. I Sametingrädets melding om samiske museer 2004 er definisjonen på et samisk museum en institusjon som virker i en samisk samfunnskontekst, at det bedriver innsamling, bevaring og formidling av samisk materiell og immateriell kultur og at det har samisk kultur- og naturhistorie som ett sentralt virkeområde. Det må imidlertid også ha en forvaltningsmessig tilknytning til Sametinget, der Sametinget er faglig og politisk premissleverandør. Nord-Troms $\mathrm{Mu}$ seum oppfyller de to førstnevnte kriteriene, men ikke det siste da museet hører inn under KKD. Nord-Troms Museum er derfor ikke et samisk museum.

At dette punktet er viktig, må sees i sammenheng med lovverk og internasjonale konvensjoner som mangfoldsåret ideologisk bygger på. Samene som folk har en sterk rettsstilling i Norge. Dette er hjemlet i det nasjonale lovverket, først og fremst gjennom grunnlovens $\$$ $110 \mathrm{a}$, hvor det fremkommer at det påligger staten å legge forholdene til rette for at samene 
148 kan sikre og utvikle sitt språk, kultur og samfunnsliv.

Samene har også fått en sterk rettstilling gjennom Norges ratifisering av ILO konvensjon nr. 169 om urfolk og stammefolk $i$ selvstendige stater den 20. juni 1990. I denne sammenheng er artikkel 7 av særlig interesse:

Vedkommende folk skal ha rett til å vedta sine egne prioriteringer forutviklingsprosessen i den grad den angår deres liv, tro, institusjoner, åndeligevelvære og de landområder de lever eller bruker på annen måte, og til så langtsom mulig å utøve kontroll med sin egen økonomiske, sosiale og kulturelle utvikling.

Sametinget legger med andre ord en langt strengere tolkning av på egne premisser til grunn enn det staten gjør, blant annet hjemlet i ILO-konvensjon nr. 169. Dette innebærer at delt forvaltningsansvar avvises.

Betyr dette at Sametinget er mot formidling av kulturelt mangfold? Det er heller slik at Sametinget vektlegger mangfold innenfor det samiske samfunn. Det samiske folk tilhører en rekke ulike grupper, som også snakker ulike språk og har distinkte dialekter. Samer er ikke bare samer, de er for eksempel skoltesamer, markasamer, sjøsamer og reindriftssamer.

Sett i lys av rettighetsspørsmål knyttet til urfolk samt de prosessene samer har vært utsatt for av et majoritetssamfunn, er det svært forståelig av Sametinget ønsker en forvaltningsmessig og politisk kontroll over formidlingen av egen historie.

\section{NoRd-TRoms MuSEUm SOM SAMISK MU- SEUM}

Disse føringene som Sametinget legger på museumssektoren, har gitt konkrete utslag i Nord-Troms. I 2003 ble det inngått en avtale mellom Nord-Troms Museum, Ája Samisk Senter og Kåfjord kommune om at NordTroms Museum skulle bygge opp et nasjonalt sjøsamisk museum ved Ája Samisk Senter i Kåfjord kommune. I Stortingsproposisjon nr. 1 (2004-2005) kom tredje byggetrinn på Ája Samisk Senter med i oversikten over nasjonale kulturbygg som skulle prioriteres i perioden 2005-2008, herunder oppbyggingen av det sjøsamiske museet. At Nord-Troms Museum skulle bygge dette opp og drive det, ble også stadfestet 14. juli 2005 i møte mellom Ája Samisk Senter, Kåfjord kommune, Troms fylkeskommune og Sametinget.

Nord-Troms Museum leverte i sakens anledning utredningen Forholdet mellom NordTroms Museum og sjøsamisk museum ved Aja Samisk Senters tredje byggetrinn i november 2004 (Nilsen 2004 b). Da Nord-Troms Museum formidler både norsk, kvensk og samisk kulturhistorie, ble løsningen om å legge hele museet inn under Sametinget ikke sett på som tilfredsstillende. Museet anbefalte derfor en delt forvaltningsmodell med utskilling av en samisk avdeling underlagt Sametinget, både faglig og økonomisk.

Samtidig startet Sametinget et utredningsarbeid for å avklare Sametingets museumsstruktur i nordre Nordland og Troms. Bakgrunnen for utredningen var å finne i norsk politikk generelt der en de siste årene har prioritert å foreta sammenslåinger av museer. Forut for konsolideringen av sektoren besto det norske museumslandskapet av mer enn 700 selvstendige enheter. For å stimulere til sammenslåinger ble det på bakgrunn av Stortingsmelding 22 (1999-2000) Kjelder til kunnskap og oppleving avsatt 202 millioner kroner over en fem års opptrappingsperiode. Målsettingen med konsolideringene var at museumssektoren skal bestå av rundt 100 fag- 
lig kvalifiserte og økonomisk handlekraftige institusjoner som skal samarbeide i nasjonale nettverk (Stortingsmelding 48 2002-2003 Kulturpolitikk fram mot 2014).

Utredningen ble behandlet i Sametinget i 2006, hvor en vedtok at Nord-Troms Museum ikke skulle ha ansvar for å bygge opp et nytt nasjonalt sjøsamisk museum. Dette henger sammen med at Nord-Troms Museum ikke er, i alle fall i tilstrekkelig grad, et samisk museum. Rent retorisk var dette tydelig også i høringsprosessen rundt meldingen. I den første utsendte versjonen, ble museer som forvaltningsmessig hører inn under KKD, kalt Ikke-samiske museer. I den endelige versjonen ble imidlertid dette moderert noe til at de samiske museene ble kontrastert til øvrige museer, gruppen som Nord-Troms Museum ble å høre til.

Byggingen av et sjøsamisk museum ved Ája var allerede finansiert via Stortingsproposisjon nr. 1 (2004-2005). Sametinget vedtok derfor at det skulle opprettes et helt nytt samisk museum i dette området som i sin helhet skulle bli underlagt Sametingets forvaltning. Dette museet har Ája Samisk Senter nå fått ansvar for å etablere og drive (Sametingets vedtak i sak 06/07 Delutredning om samisk museumsvirksomhet i Nordre Nordland og Troms, punkt II a). Dette betydde i praksis at Sametinget avviste muligheten for et delt forvaltningsansvar med KKD.

Som museum må en akseptere at Sametingets holdning om at samiske museer skal være underlagt Sametinget i sin helhet er et ufravikelig krav og at dette er noe som er hjemlet i et nasjonalt og internasjonalt lovverk med siktemål beskyttelse av urfolk. I praksis, sett fra et musealt ståsted, kan en imidlertid se at dette holdepunktet medfører visse problemer.

Vedtaket i Sametinget har i praksis innebå- ret at en har fătt en "overlappende" museums149 struktur i dette området da Nord-Troms $\mathrm{Mu}$ seum og Midt-Troms Museum er allerede eksisterende organisasjonen innenfor de geografiske rammene til det nye nasjonale sjøsamiske museet. Og Nord- og Midt-Troms Museum formidler samisk kulturhistorie.

I det Sametinget sa nei til en delt forvaltningsmessig løsning, og eierne av Nord-Troms Museum ikke ønsket at kun Sametinget skulle være premissleverandør, har resultatet blitt at Sametinget ikke får noen innflytelse over museumsdriften ved Nord-Troms Museum. Dette er fra et museumsfaglig ståsted ikke heldig, da museet har en stor samling samisk materiale, både bygninger, gjenstander og foto. I praksis innebærer dette at Nord-Troms $\mathrm{Mu}$ seums store samlingen tilhører et museum underlagt KKD, mens det nyetablerte nasjonale sjøsamiske museet ved Ája Samisk Senter per dags dato ikke har et eneste objekt i sin samling.

Sametingets vedtak kan også synes noe rigid, da delt ansvar for sentrale kulturelle virksomheter har blitt akseptert $\mathrm{i}$ andre tilfeller. Stiftelsen Lásságámmi ble etablert i 2004 og er eid av Sametinget, Storfjord kommune, Troms fylkeskommune og Universitetet i Tromsø. Lásságámmi var multikunstner NilsAslak Valkeapääs bolig inntil hans død. Stiftelsen forvalter rettighetene til hans åndsverk og har også åpnet opp huset, som i stor utstrekning står slik Valkeapää etterlot seg det, som kunstnerbolig samt for publikum i begrenset tid og omfang. ${ }^{16}$ I dette tilfellet er institusjonen som det er et delt eierskap av, ikke et museum, men en institusjon hjemmehørende innenfor en bredere kultursektor. En kan kanskje stille seg noe undrende til hvorfor Sametinget er meget streng i sitt krav om forvaltningsmessig tilhørighet når det gjelder et 
150 museum som Nord-Troms Museum, når delt model aksepteres i tilknytning til en stiftelse som forvalter en av de mest betydningsfulle samiske kunstneres arv.

\section{HVORFOR KUNNE IKKE NORD-TROMS MU- SEUM BLI ET MUSEUM UNDER SAMETINGET?}

Siden Sametingets vedtak ikke ble sammenfallende med Nord-Troms Museums ønsker, kan en stille spørsmålet: Hvorfor kunne ikke Nord-Troms Museum rett og slett endret den forvaltningsmessige tilknytning og startet en prosess der museet ble lagt under Sametingets forvaltning i sin helhet? På den måten ville man ha oppnådd en mer oversiktelig, og ikke "overlappende" museumsstruktur. Dermed ville man også kunne samlet det faglige miljøet i en større, og mer slagkraftig organisasjon. Et Nord-Troms Museum som i sin helhet var blitt lagt forvaltningsmessig under Sametinget ville da også fått aksept for å være et samisk museum fra samenes folkevalgte organ.

Den primære årsaken til at dette ikke lar seg gjøre er å finne i det komplekse etniske og politiske landskapet som gjøres opp av de seks kommunene som eier Nord-Troms Museum. Bindingen til det politiske nivået er sterkt da det er ordførerne i hver av kommunene som utgjør museets årlige bedriftsforsamling.

Selv om den samiske, kvenske og norske befolkningen har en lang historie i alle de seks kommunene, fremstår de ulike kommunene $\mathrm{i}$ dag forskjellige. Enkelte av kommunene har valgt å fremstille seg etnisk nokså nøytralt, noe som i praksis innebærer at de fremstår som norske. Ett eksempel på dette er Skjervøy, der den sentrale identiteten er knyttet til fiskerier og sloganet Skjervøy - Kystbyen i nord.

Kåfjord fremstår som en av kommunene hvor samer er mest synlige. Da Samisk språ- klov ble vedtatt i 1990, var Kåfjord kommune den eneste kommunen utenfor Finnmark som ble omfattet av loven. At Kåfjord kom med i forvaltningsområdet for samisk språk førte til at det offisielle navnet på kommune ble endret til Gáivuona suohkan - Kåfjord kommune. All offisiell skilting og informasjon er på to språk, det bevilges midler til språkstimulerende tiltak via Sametinget og et eget språksenter ble opprettet i 1994 (Antonsen 2004:168-169).

Nordreisa kommune har på sin side i de senere år særlig vektlagt å synliggjøre kvensk kultur gjennom blant annet flere navneprosjekt (se for eksempel Imerslund 2008, Imerslund et al. 1993) og Baaskifestivalen. Kommunen har også de siste årene vært ledet av ordfører fra Fremskrittspartiet. Selv om partipolitikken på lokalt plan har fremstått som mer pragmatisk enn opptatt av å følge partiprogram, er likevel dette partiet det eneste i Norge som har uttrykt at det ønsker å avvikle Sametinget (Fremskrittspartiets Prinsipp og handlingsprogram 2005-2009: 11).

Holdningene til Sametinget er dermed ulike. Svært mange, både av lokalbefolkningen og politikere, finner Sametinget som en helt uproblematisk størrelse og oppfatter dette som en folkevalgt organ på linje med Stortinget. Det er likevel klart at det også er mange, hjemmehørende i både Fremskrittspartiet og andre partier, som ønsker Sametinget avskaffet eller som ikke vil bli forvaltet av det. At museets eiere ønsket en delt modell indikerer også at en full forvaltningsmessig tilknytning til Sametinget ikke ble oppfattet som helt uproblematisk.

Resultatet av Sametingets definisjon av samisk museum og vedtak om oppbyggingen av et nasjonalt sjøsamisk museum ved Ája Samisk Senter blir dermed spissformulert at uansett hvor mye samisk kulturhistorie Nord- 
Troms Museum enn formidler, hvor samiske enn de ansatte er, blir Nord-Troms Museum ikke et samisk museum av mangel på forvaltningsmessig tilknytning til Sametinget.

Dette er ikke kun et syn som er forfektet av Sametinget. I flere sammenhenger i lokalsamfunnet har jeg også møtt på beskrivelser av Nord-Troms Museum som et dádda-museum, ${ }^{17}$ hvor dette er negativt betont. Dette har uten tvil blitt oppfattet som til dels smertefullt for en ansatt som meg selv som har arbeidet mye med samiske spørsmål og som også selv har samisk bakgrunn.

\section{NoRd-TROMS Museum Og KVENER}

For å gjøre museumslandskapet enda mer komplekst for Nord-Troms Museums del, har organisasjonen som siktemål å være et kvensk museum. At dette også byr på utfordringer, har blitt aksentuert gjennom at museet nå står overfor en tilsvarende prosess som den med Sametinget og Ája Samisk senter overfor kvener og utvidelsen av Halti i Nordreisa kommune.

Nordreisa kommune startet arbeidet med et Regionens hus i 1998, som senere har skiftet navn til Halti. Første byggetrinn ble realisert i 2001. Det arbeides nå med å få fullfinansiert neste byggetrinn hvor en, blant annet fra kommunalt og fylkespolitisk hold, har signalisert et ønske om å etablere et kvensk museum. Fra fylkeskommunalt hold er det klart signalisert at dette nye museet er tenkt å bestå av en sammenslåing av Nord-Troms Museum, Reisa nasjonalparksenter og et prosjekt, Halti kvenkultursenter, som det arbeides med å gjøre om til en permanent organisasjon.

For kvenene har Europaradets rammekonvensjon av 1. februar 1995 om beskyttelse av nasjonale minoriteter stått sentralt de senere år. Selv om denne konvensjonen ikke gir kvenene like sterk rettstilling som samene har i lys av ILO konvensjon nr 169, ligger den samme forståelsen om et folks rett til selvbestemmelse til grunn også i Europarådets rammekonvensjon. Av artikkel 5.1. fremgår det at:

Partene forplikter seg til å fremme de forutsetninger som er nødvendige for at personer som tilhører nasjonale minoriteter, kan bevare og utvikle sin kultur, samt bevare de grunnleggende bestanddelene av sin identitet, det vil si deres religion, språk, tradisjoner og kulturarv.

Videre heter det i artikkel 15 at "partene skal skape de forutseninger som er nødvendige for at personer som tilhører nasjonale minoriteter, sikres effektiv deltakelse i det kulturelle, sosiale og økonomiske liv og i offentlige anliggender, særlig de som berører dem.”

17. mars 1999 ratifiserte Norge rammekonvensjonen om vern av nasjonale minoriteter, som ble gjeldende fra 1. juli samme år. Konvensjonen ble fulgt opp i Stortingsmelding nr. 21 (1999-2000) Menneskeverd i sentrum handlingsplan for menneskerettigheter og Stortingsmelding nr. 15 (2000-2001) Nasjonale minoriteter i Noreg - Om statleg politikk overfor jødar, kvener, rom, romanifolket og skogfinnar. Gjennom dette ble kvenene anerkjent som en nasjonal minoritet, mens kvensk ble anerkjent som eget språk i 2005.

På samme måte som $\mathrm{i}$ forhold til samene som urfolk, er det viktig at kvenene blir hørt om Nord-Troms Museum også skal være et kvensk museum. Hvem er det da som skal representere kvenenes stemme i museet? Fra samisk hold er det $\mathrm{i}$ alle fall klart hvem denne parten er, siden Sametinget er et representativt folkevalgt organ. Når det gjelder kvener, vil motparten bli en interesseorganisasjon. De 
152 anslagsvis 10000 til 15000 personene med kvensk opphav i Norge, er tilknyttet ulike sådanne. De senere år har Norske Kveners Forbund/Ruijan kveeniliitto fătt sentral betydning, blant annet gjennom å være høringsinstans i Stortingets behandling av saker som vedrører kvener. Foreningen, som ble stiftet i 1987, har rundt 700 medlemmer. $^{18}$

Norske Kveners Forbund/Ruijan kveeniliitto har en særstilling innenfor det kvenske samfunnet. Det er likevel ikke til å stikke under en stol at det har vært en del konflikter innenfor kvenske organisasjoner, noe som ikke nødvendigvis gjør det lettere for et museum å navigere lytefritt. I Nord-Troms er det to lokallag som er medlemsforeninger i Norske kveners forbund, henholdsvis Norsk-Finsk forening i Nord-Troms/Pohjois-Tromsin Norja-Suomi-Seura og Skibotn kvenforening/ Yykeänperän kveeniseura. Ulike konflikter de senere år har ført til at det har vært til dels høy temperatur mellom lokallag og forbundsstyret og også kvenske foreninger og Sametinget. ${ }^{19}$

En skal imidlertid ikke overdrive de interne stridighetene, og forskuttere at dette kan by på problemer sett i relasjon til Nord-Troms $\mathrm{Mu}-$ seums arbeid med kvensk kulturhistorie. Det en likevel skal være oppmerksom på er at museet kan komme til å havne i krysspress mellom samer og kvener, om gruppenes syn ikke er sammenfallende. Selv om det er både samarbeid og sammenfall i interesser mellom Sametinget og Norske Kveners Forbund/Ruijan kveeniliitto, finnes det også eksempler på det motsatte. Dette har blant annet kommet til uttrykk i forhold til Finnmarkseiendommen og pressestøtte til samiske og kvenske aviser.

Frem til 1. juli 2006 var om lag 96\% av grunnen i Finnmark fylke eid av den norske stat. Fra 1. juli 2006 ble disse enorme arealene overført til Finnmarkseiendommen. Eien- dommen ledes av et styre hvor fylkestinget i Finnmark og Sametinget utnevner tre personer hver ${ }^{20}$ Norske Kveners Forbund/Ruijan kveeniliitto har med andre ord ingen representanter i styret, og kvenske rettigheter til land og vann har heller ikke blitt utredet, selv om dette ble anbefalt av Samerettsuvalget i NOU (1984:18) Om samenes rettsstilling. I et leserinnlegg i avisa Nordlys 28. januar 1999 (s. 17) gikk styret i Norske Kveners Forbund/Ruijan kveeniliitto ut mot at samene har fătt stor innflytelse:

Både forslaget om Finnmarks grunnforvaltning og samisk grunnforvaltning medfører omfattende endringer av den nåværende forvaltningen og forvaltningsmåte i retning av å gi én etnisk gruppe, samene, større innflytelse over forvaltningen. (...) De utredningene som så langt er gjort, synes å mangle noe om hvordan Finnmark er brukt som et fellesområde mellom forskjellige folkegrupper i regionen i mer enn 1000 år.

Når det gjelder pressestøtte, har det også kommet uttalelser fra Norske Kveners Forbund/ Ruijan kveeniliitto som indikerer en viss konvergens med Sametinget, selv om dette i praksis kan sies å springe ut av de norske bevilgende myndigheter politikk. Leder i Norske kveners forbund, Helge Huru, og forbundssekretær Ivar Johnsen, uttalte seg på følgende måte i avisa Ságat 24. september 2007 (s. 36):

Det må bli slutt at begrepet "urfolk" brukes som et mantra for å forsvare diskrimineringen av de nasjonale minoriteter i Norge. De kalde og brutale fakta er at de samiske avisene får med nybevilgningen 18,9 millioner kroner fordelt på tre aviser. Den kvænske avisa Ruija Kaiku får et årlig tilskudd på kroner 900 000, og sliter med å kunne gi ut et månedlig nummer.

I forhold til hvor Nord-Troms Museum står i 
prosessen i tilknytning til oppbyggingen av et kvensk museum ved Halti, er det for tidlig å konkludere hvordan dette vil gå. Det som likevel er klart, er at en også i dette tilfelle vil stå overfor utfordringer når det gjelder organisatorisk løsning. Dette henger ikke minst sammen med at Nord-Troms Museum er ønsket sammenslått med et nasjonalparksenter og et kvenkulturprosjekt. Den formelle relasjonen til Norske Kveners Forbund/Ruijan kveeniliitto er også uavklart.

\section{AvSLUTNING}

Nord-Troms Museum formidler samisk, svensk og norsk kulturhistorie og utfordrer stereotypier av det typiske. Museet har også en stab som gjenspeiler denne virkeligheten. For Staten og eierkommunene virker dette, ikke bare tilstrekkelig, men helt i tråd med de retningslinjer en legger for hva som er flerkulturelt.

Fra Sametingets side vil synet være noe annerledes. Nord-Troms Museum kan godt være et flerkulturelt museum, men det er altså ikke et samisk museum siden Sametinget ikke legger premissene for driften. Kvenene som nasjonal minoritet har heller ikke formelt sett en innflytelse på den virksomheten Nord-Troms Museums driver.

Politikk, rettigheter og maktperspektiver spiller derfor inn på om Nord-Troms Museum er tilstrekkelig samisk og kvensk til å kalle seg et samisk eller kvensk museum.

Staten har lagt ett syn til grunn for hva et flerkulturelt museum skal oppfattes som, der medbestemmelse fra urfolk og nasjonal minoritet legges til grunn. Det betyr ikke at dette urfolket eller den nasjonale minoriteten skal ha full råderett over museet. Sametinget, som representerer en minoritet i storsamfunnet og et urfolk, har krevd at et museum i sin helhet må ligge under deres forvaltning for å oppfattes som et samisk museum. I mange tilfeller er det majoritetsstemmen som blir den som gjelder. Det spesielle i dette tilfellet, er at samene er et urfolk som har en særlig rettsbeskyttelse gjennom konvensjoner som ILOs nr 169. Hvem som har mest makt i denne forbindelsen, er derfor ikke lett å gi en entydig svar på.

Mellom stat, Sameting og kvenske organisasjoner forsøker Nord-Troms Museum å formidle den flerkulturelle virkeligheten $i$ praksis. Problemer oppstår når det ikke ligger sammenfallende interesser eller forståelser til grunn. Slik eksempelet Nord-Troms viser er mangfold i praksis, et mangfold akseptert fra minoritetenes ståsted, ei utfordring å få til i daglig virke.

\section{NOTER}

1. Norsk museumsutvikling (NMU) ble opprettet i 1994. Bakgrunnen for denne etableringen var Kulturdepartementets ønske om utarbeidelse av en plan for nasjonal samordning av innsamlingen av kulturhistorisk materiale fra det 20. århundret (Gynnild 1997).

2. http://www.kultureltmangfold.no

3. http://ec.europa.eu/culture/eac/dialogue/ year2008_en.html

4. Blant annet FNs konvensjon om de sivile og politiske rettighetene (1966) og FNs konvensjon om de økonomiske, sosiale og kulturelle rettighetene(1966), FNs generelle menneskerettighetskonvensjoner, som Verdenserklæringen om menneskerettigheter (1948) og særkonvensjoner som FNs konvensjon om avskaffelse av alle former for rasediskriminering (1965) og FNs konvensjon om barnets rettigheter (1989) (se for øvrig 
http://www.fn.no/).

5. http://unesdoc.unesco.org/images/0012/001271/127160m.pdf

6. http://www.unesco.org/culture/ich/ index.php?.pg=00006

7. http://portal.unesco.org/en/ev.phpURL_ID $=31038 \& U R L \_D O=D O \_T O P I C \& U$ RL_SECTION=201.html

8. AMB-utvikling er Statens senter for arkiv, bibliotek og museum. ABM-utvikling ble opprettet i 2003, og erstattet blant annet tidligere Norsk museumsutvikling.

9. http://www.sametinget.no/kunde/filer/museumsmelding.pdf

10. http://www.kultureltmangfold.no/art.html?catid $=41 \&$ subcat $=\&$ artid $=14$

11. http://www.riddu.com

12. http://www.kvenkultursenter.no/baaski.asp

13. Dagen gryr.

14. Samefolkets sang.

15. ABM Utvikling: Statens senter for arkiv, bibliotek og museum. ABM skal "(..), som namnet vårt seier, bidra til å utvikle dei tre sektorane vi har ansvaret for, kvar for seg og saman. Vi løyver pengar og deltar aktivt som initiativtakar og samarbeidspartnar i forskjellige prosjekt ute i felten." (http://www.abm-utvikling.no/om-abmutvikling)

16. http://www.lassagammi.no

17. Samisk for nordmann.

18. http://www.kvener.no/

19. Se for eksempel Nordlys 30.3.2006 s. 58, Nordlys 11.04 .2006 s. 46, Nordlys 10.11 .2007 s. 3, Nordlys 14.07.2007 s. 46.

20. http://www.fefo.no/index.asp?startID=\&topExpand $=\&$ subExpand $=\& s t r U r l=/ /$ applications $/$ sys tem/publish/view/showobject.asp?infoobjectid $=1004636 \&$ menuid $=1001017$

\section{LITTERATUR}

Antonsen, L. 2004: Lever samisk språk i NordTroms, tross alt? I: Nilsen, G. (red.): Kulturmøter i Nord-Troms. s. 166-173. Nord-Troms Museum, Sørkjosen.

Bjørklund, I. 1985: Fjordfolket i Kvonangen: fra samisk samfunn til norsk utkant 1550-1980. Universitetsforlaget, Tromsø, Oslo, Bergen, Stavanger.

Bojer, J. 1921: Den siste viking. Gyldendal, Kristiania.

Convention for the Safeguarding of the Intangible Cultural heritage 2003.

Convention on the protection and promotion of the diversity of cultural expressions 2005.

Dahl Bratrein, H. 1998: Passio Olavi, et kildested om Finnmarksfisket på 1100-tallet. Håloygminne, nr 1/1998. s. 117-121.

Fremskrittspartiets Prinsipp og handlingsprogram 2005-2009.

Gynnild, S. 1997: Samtiden og museene: forskning og dokumentasjon. Norsk Museumsutviklings skriftserie nr. 2 1997, Oslo.

Hage, I. 1994: Sjøsamiske buer og naust. Fjærbuene i Birtavarre. Fotefar mot nord.

Hage, I. 1995: En kvengård i Reisadalen. Tørfoss. Fotefar mot nord.

Hage, I. 2008: Kvenenes bosetting og byggemåter. I: Hage, I, E. Haugdal, B. Ruud \& S. Hegstad (red.): Arkitektur i Nord-Norge. s. 236-271. Fagbokforlaget Vigmostad \& Bjørke AS, Bergen.

Hansen, L. I. \& B. Olsen 2004: Samenes historie fram til 1750. Cappelen Akademiske Forlag, Oslo. |

Hauglid, A. O. 1981: Balsfjorden og Malangens historie. Storsteinnes.

Holmesland, H. 2006: Arkivene, bibliotekene, museene $\&$ De nasjonale minoritetene. ABM-skriftserie $n$ r. 25.

Hooper-Greenhill, E. (red.) 1996: Cultural diversity: Developing museum audiences in Britain New 
York: Leicester University Press, 1996.

ILO-konvensjon $\mathrm{nr} 169$ om urfolk og stammefolk i selvstendige stater.

Imerslund, B. 2008: Kvenske personnavn. Nordreisa kommune.

Imerslund, B, A.-L. Lindgren \& P. Hiltunen 1993: Finske stedsnavn i Nordreisa. Nordreisa kommune.

Karp, I. \& S. D. Lavine (red): Exhibiting cultures: the poetics and politics of museum display. Smithsonian Institution Press, Washington.

Karp, I., S. D. Lavine \& C. M. Kreamer (red): $M u-$ seums and communities: The politics of public culture. Smithsonian Institution Press, Washington.

Larsen, A. 1912: Baivve-Alggo - muittalus. Grøndahl, Kristiania.

Mathisen, M. 2004: Med Nordlandsbåten mellom praksis og symbol: Nordnorske fiskeres strategier mot fare og grensefortsåelse 1830-1900. Hovedfagsavhandling i historie, Universitetet i Tromsø.

Minde, H. 2002: Diktning og historie om samene på Stuoranjárga. Rapport I, Skoddebergprosjektet, Diedut 2:2000, Kautokeino.

Nilsen, G. 2004a: Nord-Troms Museum 25 år. I: Nilsen, G. (red): Kulturmøter i Nord-Troms. s. 617. Nord-Troms Museum, Sørkjosen.

Nilsen, G. 2004b: Forholdet mellom Nord-Troms Museum og sjøsamisk museum ved Aja Samisk Senters tredje byggetrinn. Nord-Troms Museum november 2004.

Nilsen, G. \& M. Mathisen 2006: Nordlandsbåten og det samiske. Nordlys s. 3, 28. februar 2006.

NOU 1984: 18: Om samenes rettsstilling.

Rekdal, P. B. 1999: Norsk museumformidling og den flerkulturelle utfordringen. Norsk museumsutvikling, Oslo.

Richter-Hanssen, E. 2004: I stille ver, $i$ storm og vind. Lyngen regionhistorie. Bind II. Lyngen bygdebok, Lyngseidet.

Sametingsrådets melding om samiske museer 2004.

Sandell, R. (red.) 2002: Museums, society, inequality,
Museum meanings. Routledge London \& New York.

Sandell, R. 2003: Social inclusion, the museum and the dynamics of sectoral change. University of Leicester

Solhaug, T. 1976: De norske fiskeriers historie 18151880. Universitetsforlaget, Bergen.

SOU 2007:50 Mangfäld är framtiden.

Stortingsmelding nr. 21 (1999-2000) Menneskeverd i sentrum - handlingsplan for menneskerettighe ter.

Stortingsmelding 22 (1999-2000) Kjelder til kunnskap og oppleving.

Stortingsmelding 48 (2002-2003) Kulturpolitikk fram mot 2014.

Stortingsmelding nr. 15 (2000-2001) Nasjonale minoriteter i Noreg - Om statleg politikk overfor jodar, kvener, rom, romanifolket og skogfinnar.

Stortingsproposisjon nr. 80 (1997-1998): Om samtykke til ratifikasjon av Europarådets rammekonvensjon av 1. februar 1995.

Stortingsproposisjon nr. 1 (2004-2005) For budsjettterminen 2005. Utgiftskapitler: 300-342. Inntektskapitler: 3300-3342. Tilråding fra Kulturog kirkedepartementet av 10. september 2004, godkjent i statsråd samme dag. (Regjeringen Bondevik II).

Sundt, E. 1976: På havet. Verker i utvalg 7. Gyldendal Norsk forlag.

Universal declaration on cultural diversity 2001.

Øye, I., S. Helliesen \& B. Tønseth (red) 1994: $M$ for museum: rapport fra jubileumsseminar Oslo 3.-6. juni 1993. Norske kunst og kulturhistoriske museer, Oslo.

\section{Arkivmateriale}

Brev fra ABM-utvikling ref. 05/148-4: Overføring av forvaltningsansvaret for Sør-Varanger Museum til Sametinget

Sametinget: Vedtak sak 06/07 Delutredning om samisk museumsvirksomhet i Nordre Nordland og Troms. 
GøriLl NiLsEN

156 Aviser

Nordlys 28. januar 1999 (s. 17)

Nordlys 30. mars 2006 (s. 58)

Nordlys 11.april 2006 (s. 46)

Nordlys 10.november 2007 (s. 3)

Nordlys 14.juli 2007 (s. 46)

Ságat 24. september 2007 (s. 36)

${ }^{*}$ Gørill Nilsen

Førsteamanuensis Universitetet $i$ Tromsø og

Førstekonservator II Nord-Troms Museum

Address: Institutt for arkeologi

Det samfunnsvitenskapelige fakultet

Universitetet $i$ Tromsø

9037 Tromsø

E-mail: gorill.nilsen@sv.uit.no 